\title{
The Role of Shopping Malls on Kurdistan Regional Government's Economy
}

\author{
Bayad Jamal Ali ${ }^{1}$, Bayar Gardi ${ }^{2}$, Baban Jabbar Othman ${ }^{3}$, Bawan Yassin Sabir ${ }^{4}$, Sarhang \\ Sorguli ${ }^{5}$, Nechirwan Burhan Ismael ${ }^{6}$, Pshdar Abdalla Hamza ${ }^{7}$, Hassan Mahmood Aziz ${ }^{8}$, \\ Shahla Ali Ahmed ${ }^{9}$, Govand Anwar ${ }^{10}$
}

\author{
${ }^{1}$ Business Administration Department, Komar University of Science and Technology, Sulaimani 46001, Kurdistan Region - Iraq \\ 2,4,5 Department of Accounting, College of Administration and Financial Sciences, Knowledge University, Kirkuk Road, 44001 Erbil, \\ Kurdistan Region, Iraq. \\ ${ }^{3}$ Faculty Technology Management and Business, Universiti Tun Hussein Onn Malaysia 86400 Parit Raja, Johor, Malaysia. \\ ${ }^{6}$ Department of Accounting, Cihan University - Duhok, Kurdistan Region, Iraq. \\ ${ }^{7}$ Department of Business Administration, Kurdistan Technical Institute, Sulaymaniyah, Iraq. \\ ${ }^{8}$ Department of Accounting and Finance, Faculty of Economics and Administrative Sciences, Cyprus International University, Mersin 10, \\ Haspolat 99040, Cyprus. \\ ${ }^{9}$ Department of Guidance and Psychological Counseling, Atatürk Faculty of Education, Near East University, Turkey \\ ${ }^{10}$ Department of Business Administration, College of Administration and Financial Sciences, Knowledge University,44001 Erbil, \\ Kurdistan Region, Iraq
}

Received: 04 Feb 2021; Received in revised form: 21 Apr 2021; Accepted: 16 May 2021

C02021 The Author(s). Published by TheShillonga. This is an open access article under the CC BY license

(https://creativecommons.org/licenses/by/4.0/)

\begin{abstract}
This research covers the history of shopping malls in KRG and how the malls were a new shopping destination for the citizens of KRG. However, with the current economic crisis in KRG and the financial difficulties that people have been facing in the past two years. This research studies the impact of economy crisis on the spending's of individuals and the shopping centers that were used to be filled with people who would spend a huge amount of money on shopping. We distributed 240 questionnaires in three languages: Kurdish, Arabic and English in order to identify people's shopping behavior and the factors that attract people to the shopping malls. The things that we managed to accomplish in this research was that people are pessimistic about the financial situation and future of the economy. People would rather save their cash than spending it on shopping. These achievements met the main objective of this study which was to find out people's behavior to do their shopping and satisfy their needs and wants that are provided in the malls.
\end{abstract}

Keywords-Shopping Malls, Economic Crisis, Shopping Behavior, Kurdistan Regional Government.

\section{INTRODUCTION}

The term and idea of shopping malls existed in the world since the middle ages. The idea of departmental stores developed later in $19^{\text {th }}$ century which are known as shopping malls nowadays. Shopping malls were a new shopping destination for the citizens of the KRG, the first mall in KRG was built 12 years ago in 2004. In the past the citizens used to do their shopping in the old bazaar, the new buildings used to attract a huge number of customers, the products were appealing (Abdullah \& Othman, 2019) and it could satisfy the needs and wants of customers who were capable of buying and purchasing all kinds of goods needed in their daily lives including clothes, food, and other household goods. The new malls made a rushing and important increase in KRG (Anwar \& Abdullah, 2021). Kurdistan regional government residents and tourism had also a dramatic growing movement in the establishing of shopping malls all over the province (Top \& Ali, 2021). Shopping malls were built in KRG when the economy was at its best when there were no economic crises (Demir et al. 2020). Shopping malls are needed because it is easier having a place where there are many different shops in one place that fulfill the many different needs and wants of individuals (Gardi et al. 2020). The public in KRG not only 
use the malls to shop but it is also a place where friends meet and have fun (Prabhu et al. 2020). The shopping centers have an important and critical part in regional economy because they carry number of jobs (Anwar \& Shukur, 2015). The income of individuals was affected after opening the shopping malls in KRG because malls needed labor force, employees and workers that would get salaries from working in malls (Sultan et al. 2020). It was also a positive way to start trading between countries especially with Turkey as many brands started to open their shops in KRG (Ali, 2021). The new shopping destination increased the economic capital and wealth. It was also a way of changing lifestyle and culture transformation (Abdullah \& Othman,2015). Sadly, the year of 2014 was not a good economic year in KRG. It was troubling by economic crisis, financial crisis that was due to the war against ISIS and the decline of oil prices. This has affected the spending of individuals. The main source of public income is wages, savings, investment, retirement fund and benefits (Gardi, 2021). The KRG failed to pay the monthly payment of its employees and most of the income sources of its citizens which lead to the decrease of their expenditure. Not only was the public sector effected by this crisis but also the private sector was effected (Ismael et al. 2021) the data taken from the ministry proves that In the years ahead of the financial crisis the firms were ranked as below in 2010 the Kurdistan region had 1716 local firms and 341 foreign firms in the year 2011 local firm numbers were 1992 and 478 foreign firms in 2012, 2309 were local and 399 were foreign the number of local firms dropped in the year 2014 from 2980 in 2013 to 2214 and the foreign firms number were dropped to half from 443 in 2013 to 264 in 2014 and In the year of 2015 when the financial crisis started the number were 1426 for local firms and 105 for foreign ones. This number shows how private firms left the region or tried to reduce its expenses by cutting the numbers of employees which led to the increase in the unemployment rate (Gardi, 2021). The individual income was reduced as the prices of houses were decreased and amount of rent paid were cut to half. The failing of banks to give loans which lead people to high debt rates were all reasons that impact the shopping behavior of the public (Anwar \& Abd Zebari, 2015). All the reasons mentioned above lead to the inability of spending by individuals due to not having enough income which led to huge decrease in the number of visitors and customers of the malls (Anwar \& Surarchith, 2015). Also, the shopping centers visitors were reduced to half especially after losing tourism due to the unstable safety environment of the region (Ali, 2020). The shops inside the malls were forced to close their doors due to not having enough customers (Othman et al. 2019). The table below shows the reduce number of local and foreign firms throughout the years and especially in the years of economic crisis (Khan \& Abdullah, 2019).

\section{Aim of the study}

The aim of this study was to understand the people's perception about the current crisis in the Region of Kurdistan which consists of Political crisis, Economic crisis, Social crisis and financial crisis.

\section{Research Objectives:}

The followings are the main research objectives:

- To study the behavior of customers on unorganized and organized retail.

- To evaluate the role of both retail chain and unorganized retail on local economy.

- To identify the impact of Kurdistan region and street vendors after emergence of big capitalintensive organized retail.

\section{Research Questions}

The followings are the main research questions:

- How do families choose between different types of malls in KRG?

- Why should the government provide resources needed for the retailers and other shops in mall?

- What shapes the decision of investors to invest in KRG shopping malls? And how does the investment climate effect on their decision?

\section{LITERATURE REVIEW}

A lot of researchers have been conducted on performance of shopping malls and their effect on economy. Some authors have made research on behavior of individual in shopping malls (Othman et al. 2019). This literature includes shopping behavior, shopping value, consumer decision making styles (Anwar, 2017). The researches that were taken on shopping behavior in most of the researchers were taken from foreign understandings, there are very few studies that have actually examined the effects of the mixed characteristics of buying behavior in the shopping centers and the experience of shopping malls (Anwar, 2016). According to Abdulla et al. (2017), reflected the consequence of driving time upon the likings of purchasers towards local strip malls. They communicated that in spite of the fact that it is observed that populace acquiring power common people thickness daily paper spreading and different mechanisms are powerful in deciding the shopping proclivities for customers a variable which is by and large overlooked is the driving time required to achieve (Anwar \& Balcioglu, 2016). In this study it was built up that the 
driving time required to achieve is very powerful in deciding purchaser mall dispositions (Andavar et al. 2020). According to Abdullah \& Abdul Rahman, (2015), examination set up that the shopping center designers' benefit gathers from the development and proposition of shopping centers hire rent and origins from the retail incomes (Hameed \& Anwar, 2018). Unlike to different types of land where markets have quickly absorbed and are dependent on urban and local financial riches shopping center development has been a reasonably protected assumption (Damit et al. 2019).

\section{Shopping behavior}

This segment is attempts to offer an explanation on consumer shopping behavior by appraisal the former study on the previous literature (Prabhu et al. 2020). Shopping is one of the different activities of consumer behavior and shopping behavior is an individual form of consumer behavior (Anwar \& Ghafoor, 2017). According to Anwar \& Climis, (2017), creatures' objectives in shopping are a hint of numerous variables, some of which are irrelevant to the real purchasing of items. It is kept up that an understanding of shopping thought processes needs the thought of accomplishments which shopping trainings give, and in addition the value developed from the stock that might be achieved (Prabhu et al. 2019). On the off chance that needs other than those connected with specific items encourage individuals to go to a store, the retailer ought to join this data into his advertising system"( Anwar \& Qadir, 2017). Tuber's research hypothesized eleven motives for shopping behavior (Abdullah, 2019).

Individual motivations: Part playing (Anwar \& Louis, 2017). The role and the part that shopping plays is an activity that remains as an important part of an individual activity in each society.

- Entertainment. Besides fulfilling the needs of individuals shopping can be a stress relieve especially for women, it's an action that allows individuals and shoppers to change their repetitive activities of their everyday life.

- Information on latest activities. Individuals take shopping as a way to explore the latest fashion design, styles and trends.

- Tourism activity. Shopping malls are an attraction that attracts people especially the ones that live outside of cities.

- Luxury. Individuals with high class standards of living for them shopping will be a way of demonstrate themselves by buying whatever is expensive and unique.
- Social shopping. People get a better social life through shopping; they meet up with friends and perform fun activities.

- Sharing hobbits and benefits. People with same hobbies mostly shop from the same shops and mostly have same benefits they perform shopping with the intention to get same results.

According to Ali \& Anwar, (2021), they have anticipated seven dimensions of shopping performs. The shopping practices including probable effectiveness, part approval, transaction, decision reorganization, agreement, force and power, and incitement. By (Khan \& Abdullah, 2019), shopping conduct are connection particular; shopping has these days turned into a hang loose instead of a perfect buying action, for example, looking for essential goods, family unit things, apparel and blessings (Anwar \& Abdullah, 2021). Afterwards, the intentions and practices clear when a buyer is looking for awards are not same as those presented when customer shops for foodstuffs (Prabhu et al. 2020). Also, individual customers' foundation and dispositions towards shopping regularly change fundamentally (Ganeshkumar et al. 2019).

According to Abdullah \& Afshar, (2019), shopping behavior are context specific; shopping has nowadays become a pass-time rather than a pure purchasing activity, such as shopping for groceries, household items, clothing and gifts. Thus, the motives and behaviors evident when a consumer is shopping for gifts are not same as those exhibited when consumer shops for groceries. And, individual consumers' motive and attitudes 11 towards shopping often vary significantly. Also, according to Abdullah \& Rahman, (2015) two customers might shop at the same stores for equal reasons, e.g., comfort, respectful help enjoyable artistic theme, and so forth., however one customer my observe shopping a weight, something to be done rapidly inside of at least energy while (Ali et al. 2021) another might appreciate shopping, taking part in it as game by accomplishing the fulfillment of purchasing a coveted thing at a deal cost. This last customer does wouldn't bother spending energy skimming for options (Abdullah, 2018).

Shopping is the type of activity the researchers mean includes experiencing that a part of the world that has been considered for sale(Saleh et al. 2021), using our senses vision, touch, smell, taste, hearing - as the basis for choosing this or rejecting that essentially all unplanned consumptions and many planned ones, (Othman \& Abdullah, 2016) too come as a outcome of the shopper seeing, touching, smelling or tasting something that promise pleasure, if not total fulfillment (Abdullah \& Othman, 2016). 
It can see that individual go shopping for particular details, beside to gain a product, they also shop for non-purchase reasons (Abdullah \& Othman, 2021) such as watching for social contact, sensory stimulate, learning for new rends and even exercise. That is, consumer can shop for practical reasons related to accomplishing specific purchase goals (Abdullah \& Abdul Rahman, 2015). Otherwise, they can shop for hedonic or enjoying reasons related to having fun. According to Anwar \& Abdullah, (2021), there are six hedonic shopping motives, namely, escapade shopping (to shop for stimulus, escapade, and the feeling of being in another world), social shopping (for satisfaction shopping with friends, family, socializing while shopping, and bonding with others while shopping) (Anwar \& Shukur, 2015), satisfaction shopping (for stress issue, to improve a negative mood, and shopping as a special treat to oneself, idea shopping (to keep up with movement and new style, and to see new products and inventions), role shopping (Anwar \& Abd Zebari, 2015) (for fun of shopping for others), and value shopping (refer to shopping for sales, observing for discounts) (Anwar \& Surarchith, 2015).

\section{Shopping value}

Defines value as a constant belief that a specific mode of behavior or finish state of existence is individually or socially desirable to an opposite or reverse (Anwar, 2017) mode of behavior or end-state of reality. Preceding researcher have found that values affect various characteristics of consumption conducts and attitudes. Anwar, (2016), has recommended that perceived value can be observed as a "shopper's (Abdulla et al. 2017) overall valuation of the value of a product (or service) based on observations of what is received and what is given (Anwar \& Balcioglu, 2016).

The valuation here is referred to a connection of a product or service's get and give components (Hameed \& Anwar, 2018). The best common explanation of value is the percentage or tradeoff between price and quality. According to Anwar \& Ghafoor, (2017), the value in the background of shopping is "all factors, both quantitative and qualitative, objective and subjective, that make up the complete shopping skill (Faraj et al. 2021). This explanation identifies clearly value's individual nature. Here, value is providing by the complete shopping knowledge not only by product gaining. Also, according to Anwar \& Climis, (2017), shopping performance is reliant on shoppers' value and attitude to the mall environment and store atmospherics. These values exist in shoppers' culture and personal characters. Among the shopping value study that carry out useful and hedonic value are the two-shopping value often recognized. The useful dimension of shopping has been the main focus of marketing investigators (Anwar \& Qadir,
2017). In common consumers pursuing useful value can be identify as task-related and normal; focused on decision usefulness. Also, the useful shopping value can be correlated to the customer's need to obtain some useful penalties from visiting a store and combines aspects such as shopping convenience and recognized risk (Anwar \& Louis, 2017). Hedonic shopping value can be correlated to the consumer's need to obtain fun and pleasure and relates to the perceived level of shopping enjoyment (Anwar \& Abdullah, 2021). Advanced and validated a scale to quantity consumer's assessments of a shopping experience along the useful and hedonic value (Ali, 2016). According to Anwar \& Abdullah, (2021), the utilitarian value with a work attitude while hedonic value is more subjective, individual and results more from fun and playfulness related with shopping experience. Anwar \& Abdullah, (2021), have expanded the study on hedonic shopping motivation and advanced a six-factor scale that involves of adventure, satisfaction, role, value, social, and knowledge shopping motivation. In common, shopping value is among shoppers and these effects their (Anwar \& Shukur, 2015) consumption performances and attitudes. So, by using certain scales advanced in the previous research we can classify shopper perceived shopping values (Anwar \& Abd Zebari, 2015).

\section{Consumer decision-making styles}

In bid to study why and how individuals shop researchers classify the clients shopping conduct based on their decision-making style. Consumer decision-making style may be explained as a psychological orientation define a consumer's style to making selections (Anwar \& Surarchith, 2015). They trust that consumers involve in shopping with certain important choice making types or styles plus rational shopping awareness regarding price, brand and quality among others (Anwar, 2017). The influence of retail outlets and malls on the purchase behavior of middle-class consumer's, Notes that the successful prepared retail chains and also the malls in the state, today operate at regional sections and are not targeting at the national attendance at least for the time existence (Anwar, 2016). In command to reach all classes of the society organized retail arrangements should design a complete and prospective business model which need the quality or value of product / services at cheap prices and generate more socially stable business (Abdulla et al. 2017).

\section{METHODOLOGY}

\section{Design of the study}

The researcher used a questionnaire in order to gather data about the shopping. The questionnaire was composed of two sections. The first section consisted of demographic 
questions, starting with the participant's (gender, age, level of education, occupation, household income). The second section of the questionnaire consisted 4 different dimensions (Entertainment attraction of the center, the centers building, Center's design and Features of centers).

\section{Procedures used for generating, collecting and evaluating data}

The researcher collected data for the study through distributing questionnaire as primary data. The questionnaire is prepared and distributed to the students, owner of shops, business and political men. Secondary data is needed for conducting research work, which is done by collecting it from recent academic articles, books, and previous studies related to shopping malls and retailer stores.

\section{Sampling size and target population}

A random sampling method was adopted to gather data. The sample consisted of the employees, students, business man, owner of shops and businessmen, etc. in Erbil. Where all the population of this study will be 240 units and the sample size of this study was 240 .

\section{Instrument for measuring (scales)}

The questionnaire is structured in the form of multiplechoice questions. The participants were asked to rate how strongly they agree on each item on a five-points Likert order scale.

\section{DATA ANALYSIS}

As seen in table (1) that 114 of the participants were male and 126 were females. The questionnaire was used to target certain audience but the researchers also wanted to have a

wider knowledge of what other types of audience think of the situation. The main target was female and therefore, the researchers decided to have more female than male participants. the researchers believe that the shopping malls mostly affected the females of the targeted population. To measure participants' age, the researchers used four groups of ages, as seen is Table-2 and Graph-2, one is below 20 and another category is $(21-30)$ and third one is $(31-40)$ other category is above 40.34 were below 20 and 119 participants were (21-30) and 51 were (31-40) and 36 were above 40. As the results above show us that the candidates participated in the questionnaire are mostly in the ages (21-30) which were actually the main target. To measure participants' occupation, 19 less than secondary school,46 was secondary school, 107 were junior college, 49 were college graduated and 19 were postgraduate degree. In this question, the researchers wanted to find out what is the education level of the participants and the most common education. This question was helpful to find how the current situation affected each level of education and which level of education are more interested in shopping. And the figure showed us that most of college students which is $44.6 \%$ in KRG are more interested in shopping than other level of education.

Table 1- Demographic Analysis

\begin{tabular}{|c|c|c|c|c|}
\hline No & Items & Scales & Frequency & Percent \\
\hline \multirow[t]{2}{*}{1} & \multirow[t]{2}{*}{ Gender } & Male & 114 & 47.5 \\
\hline & & Female & 126 & 52.5 \\
\hline \multirow[t]{4}{*}{2} & \multirow[t]{4}{*}{ Age } & Below 20 & 34 & 14.2 \\
\hline & & $21-30$ & 119 & 49.6 \\
\hline & & $31-40$ & 51 & 21.3 \\
\hline & & Above 40 & 36 & 15.0 \\
\hline \multirow[t]{5}{*}{3} & \multirow[t]{5}{*}{ Education } & less than secondary school & 19 & 7.9 \\
\hline & & secondary school & 46 & 19.2 \\
\hline & & junior college & 107 & 44.6 \\
\hline & & college graduate & 49 & 20.4 \\
\hline & & postgraduate degree & 19 & 7.9 \\
\hline
\end{tabular}

As seen in Table (2), that 40 persons strongly disagreed, 27 persons disagreed, 92 persons were normal, 53 persons agreed and 28 persons strongly agree. With this question, the researchers wanted to find out that how participants are thinking and satisfied with music at center. To prove that the participants are natural with the statement the results above are very clear. As for second question, was to find out how population are satisfied with level of volume during 
shopping at malls. As the results show that the think of the participants $9.6 \%$ are strongly disagreed, $12.5 \%$ disagreed, $38.3 \%$ are normal that means most of buyer are satisfied with volume, $25.4 \%$ agreed and rest which is majority of the participants of $14.2 \%$ are strongly agreed. This question was helpful to find how the people are enjoying listening to music at appropriate volume and are enjoying their time. As for third question, was to find out how people are thinking about lighting and how affected the buyer to visit shop. As the results show that the think of the participants $9.2 \%$ were strongly disagreed, $10.4 \%$ disagreed, $34.2 \%$ were normal, $29.4 \%$ were agreed and $16.7 \%$ were strongly agreed. As for fourth question, the results are varied, $8.8 \%$ strongly disagreed, $14.6 \%$ disagreed, $32.1 \%$ normal, $22.5 \%$ agreed and $22.1 \%$ strongly agreed. The majority of the targeted population that are comfortable with claimant in side malls while doing their shopping. As for fifth question, the purpose of this question was to find out if the participants attracted by the architecture of malls in KRG and affect them to visit malls for more than one time.7.9\% were strongly disagree with idea of architecture, $11.3 \%$ were only disagree, but most of them which is $31.3 \%$ were normal with architecture of malls, $22.9 \%$ were agree and latest think was $26.7 \%$ were strongly agree. That mean this question was helpful to find that above $45 \%$ were totally agree with the idea of center's architecture gives attractive character to gain more buyers in KRG. As for sixth question, the purpose of this question was to find out how the participants are thinking about the wall and floor color if is it interested to them or not as we see here that $17.5 \%$ were agreed, $29.6 \%$ were strongly agreed, $7.5 \%$ were strongly disagreed, $12.9 \%$ were disagreed and $32.5 \%$ which is the highest were normal that the color of wall and floor is not affected that much on shopping. As for seventh question, the findings showed that $13,33.8 \%$ of the population agreed that the overall design of the center interest them in their shopping. While $14.2 \%$ of the population disagreed and had no interest in the overall design. $28.3 \%$ of the population thought that the look of the mall was neutral with their shopping behavior. $18.3 \%$ strongly agreed that their ability to do shopping increased with the overall look of the shopping center, the better the design was the times of their visit to the center increased. As for eighth question, the findings showed that $5.4 \%$ of the population were not interested in the way the center looked and their shopping behavior had no association with the design.

As for ninth question, the findings showed that the highest present of the population which is $31.7 \%$ agreed that the layout of the center is important and it makes getting to stores easier. $30.8 \%$ of the population that visited the KRG shopping center thought that it is normal to have layout or not. $22.1 \%$ strongly agreed with having layout in the centers of shopping. 9.6\% were not in need for layouts and disagreed with the idea that layout makes it easier to get to the stores. $5.8 \%$ of the visitors of the center strongly disagreed with the idea that the layout of the center makes it easy to get to the stores. As for tenth question, it was found that with the answering the question if the layout makes it easy to get to the food are, $7.9 \%$ of the visitors disagreed and they expressed that to get to the food are the layout was not important. $9.2 \%$ of the center visitors strongly disagreed with the idea of having layout to get to the food area. On the other hand, $34.6 \%$ and the highest percent of the visitors agreed and thought that layout makes it easy to get to the food area. The second highest percentage of the visitors which is $27.5 \%$ were neutral with the need of the layout to find food area. $20.8 \%$ of the visitors strongly agreed with the need of layout to get to the food area. As for eleventh question, it was found that the guests of the mall expressed their need of the layout to find restrooms in the shopping center in the KRG. The ones that agreed with the need of having layout to find restrooms were the highest percentage which was $30 \%$. The ones that disagreed with having layout in the mall that shows the way to the restrooms were $10.8 \%$. The lowest number of guests in the mall as low as $9.2 \%$ strongly disagreed with having restrooms shown in layout. $29.6 \%$ of the guests in the mall that answered this question believed that it is a normal thing that layout dose makes it easy to find restrooms. And $20.4 \%$ of the guests in the mall stated that they strongly agreed with having layout in the mall that shows the way to find restrooms. As for twelfth question, it was found that the visitors of the mall expressed their need of the layout in the center to help them with getting around in the mall. $28.3 \%$ of the visitors that participated in this research agreed with having layout in center and the help they provide with getting around the mall. $12.5 \%$ of the visitors disagreed with the idea of having layout and thought the getting around the mall does not need layout. $11.3 \%$ strongly disagreed and thought that going around the mall is easy enough. $19.2 \%$ strongly agreed with having layout in the center and thought that without layout they could get lost. A good number of visitors which was $28.8 \%$ felt neutral with having layout in the mall. They felt that it is a necessary within the center to have layout no matter what the purpose is. As for thirteenth question, it was found that the visitors expressed their opinion with the quality of the food offered in the shopping center. $27.5 \%$ of the costumers in the center thought that the quality of the food in the mall was normal for them and thought that it doesn't have much difference with other shopping centers. $25.8 \%$ agreed that the food in the center is excellent. $20 \%$ strongly agreed with the quality of the food offered in the center and voted for it as it's their favorite place. $16.3 \%$ of the center visitors disagreed with having to eat in the center 
and the food served in the mall got a low rate from them. $10.4 \%$ of the visitors in the mall strongly disagreed with the Excellency of the food offered in the center and they refused to have a single meal in the center. As for fourteenth question, it was found that considering the variety of stores available in the center the responses of the costumers were like this, $27.1 \%$ of the costumers in the center were not satisfied with the number of different stores in the mall that offered different products. $12.5 \%$ strongly disagreed with the verity of stores and $14.6 \%$ disagreed that there are a lot of different options in the center. $24.6 \%$ believed that the number of stores is ok, in other words not too good not too bad. $27.5 \%$ agreed on the verity of stores and were happy and satisfied. The $20.8 \%$ of the final costumers of the center strongly agreed that the Varity of stores in the mall is perfect.

As for fifteenth question, it was found that the center entertainment activities in the mall got quite good results. The costumers in the mall responded like this, $18.8 \%$ strongly agreed that besides shopping there are a lot of entertainment activities within the center that a visitor can enjoy while or after shopping. $24.6 \%$ agreed that the entertainment alternatives are excellent within the center. $30 \%$ of the costumers found that the fun activities in the mall were normal. $9.2 \%$ strongly disagreed and did not like the entertainment alternatives. $17.5 \%$ disagreed and voted for the entertainment alternatives as boring. As for sixteenth question, it was found that the amount of time spent in the mall by its costumers was low. $37.1 \%$ of the mall visitors felt that it is normal to stay in the mall and that they don't mind. $17.1 \%$ agree that they would like to stay in the mall as long as possible, and $16.3 \%$ strongly agree with the fact that staying in the mall is very fun and they would spent their whole day in the center if they could. $11.7 \%$ of the costumers of the mall for some reason didn't like to spend too much time in the center and they would rather do their shopping and leave. $17.9 \%$ of the center only visit it to get their needs and leave as fast as they could. As for seventeenth question, the researchers asked in research if people in the mall enjoy their time. And the responds were that $38.8 \%$ felt normal with their visit to the mall. While the $25.8 \%$ agreed that they enjoyed their visit to the mall and they would like to come back. $16.3 \%$ strongly agreed on the fact that they have lots of fun in the mall and enjoy their time and they would visit again as soon as they can. With that percentage combined $80.9 \%$ of the visitors in the mall enjoy the time they spent with their family and friends in the mall shopping and doing enjoyable activities. $9.6 \%$ of the visitors seem to disagree with the rest of visitors and they did not enjoy the time they have spent in the mall. $9.6 \%$ strongly disagreed with the center being an enjoyable place.

Table 2- Descriptive Analysis

\begin{tabular}{|c|c|c|c|c|}
\hline No & Questions & Scales & Frequency & Percent \\
\hline \multirow[t]{5}{*}{1} & \multirow[t]{5}{*}{$\begin{array}{l}\text { Shopping center plays music that } \\
\text { I like }\end{array}$} & $\begin{array}{l}\text { Strongly } \\
\text { disagree }\end{array}$ & 40 & 16.7 \\
\hline & & Disagree & 27 & 11.3 \\
\hline & & Normal & 92 & 38.3 \\
\hline & & Agree & 53 & 22.1 \\
\hline & & $\begin{array}{l}\text { strongly } \\
\text { agree }\end{array}$ & 28 & 11.7 \\
\hline \multirow[t]{5}{*}{2} & \multirow[t]{5}{*}{$\begin{array}{l}\text { Center music is played at an } \\
\text { appropriate volume }\end{array}$} & $\begin{array}{l}\text { strongly } \\
\text { disagree }\end{array}$ & 23 & 9.6 \\
\hline & & disagree & 30 & 12.5 \\
\hline & & normal & 92 & 38.3 \\
\hline & & agree & 61 & 25.4 \\
\hline & & $\begin{array}{l}\text { strongly } \\
\text { agree }\end{array}$ & 34 & 14.2 \\
\hline \multirow[t]{4}{*}{3} & \multirow[t]{4}{*}{ The center lighting is appropriate } & $\begin{array}{l}\text { strongly } \\
\text { disagree }\end{array}$ & 22 & 9.2 \\
\hline & & Disagree & 25 & 10.4 \\
\hline & & Normal & 82 & 34.2 \\
\hline & & Agree & 71 & 29.6 \\
\hline
\end{tabular}




\begin{tabular}{|c|c|c|c|c|}
\hline & & $\begin{array}{l}\text { strongly } \\
\text { agree }\end{array}$ & 40 & 16.7 \\
\hline \multirow[t]{5}{*}{4} & \multirow[t]{5}{*}{$\begin{array}{l}\text { The center temperature is } \\
\text { comfortable }\end{array}$} & $\begin{array}{l}\text { strongly } \\
\text { disagree }\end{array}$ & 21 & 8.8 \\
\hline & & Disagree & 35 & 14.6 \\
\hline & & Normal & 77 & 32.1 \\
\hline & & Agree & 54 & 22.5 \\
\hline & & $\begin{array}{l}\text { strongly } \\
\text { agree }\end{array}$ & 53 & 22.1 \\
\hline \multirow[t]{5}{*}{5} & \multirow[t]{5}{*}{$\begin{array}{l}\text { Center's architecture gives it an } \\
\text { attractive character }\end{array}$} & $\begin{array}{l}\text { strongly } \\
\text { disagree }\end{array}$ & 19 & 7.9 \\
\hline & & Disagree & 27 & 11.3 \\
\hline & & Normal & 75 & 31.3 \\
\hline & & Agree & 55 & 22.9 \\
\hline & & $\begin{array}{l}\text { strongly } \\
\text { agree }\end{array}$ & 64 & 26.7 \\
\hline \multirow[t]{5}{*}{6} & \multirow[t]{5}{*}{$\begin{array}{l}\text { The center is decorated in } \\
\text { attractive fashion }\end{array}$} & $\begin{array}{l}\text { strongly } \\
\text { disagree }\end{array}$ & 17 & 7.1 \\
\hline & & disagree & 37 & 15.4 \\
\hline & & normal & 69 & 28.8 \\
\hline & & agree & 75 & 31.3 \\
\hline & & $\begin{array}{l}\text { strongly } \\
\text { agree }\end{array}$ & 42 & 17.5 \\
\hline \multirow[t]{5}{*}{7} & \multirow[t]{5}{*}{$\begin{array}{l}\text { Interior wall and floor color } \\
\text { schemes are attractive }\end{array}$} & $\begin{array}{l}\text { strongly } \\
\text { disagree }\end{array}$ & 18 & 7.5 \\
\hline & & Disagree & 31 & 12.9 \\
\hline & & Normal & 78 & 32.5 \\
\hline & & Agree & 71 & 29.6 \\
\hline & & $\begin{array}{l}\text { strongly } \\
\text { agree }\end{array}$ & 42 & 17.5 \\
\hline \multirow[t]{5}{*}{8} & \multirow[t]{5}{*}{$\begin{array}{l}\text { The overall design of centers is } \\
\text { interesting }\end{array}$} & $\begin{array}{l}\text { strongly } \\
\text { disagree }\end{array}$ & 13 & 5.4 \\
\hline & & Disagree & 34 & 14.2 \\
\hline & & Normal & 68 & 28.3 \\
\hline & & Agree & 81 & 33.8 \\
\hline & & $\begin{array}{l}\text { strongly } \\
\text { agree }\end{array}$ & 44 & 18.3 \\
\hline \multirow[t]{4}{*}{9} & \multirow[t]{4}{*}{$\begin{array}{l}\text { The layout makes it easy to get to } \\
\text { the stores }\end{array}$} & $\begin{array}{l}\text { strongly } \\
\text { disagree }\end{array}$ & 14 & 5.8 \\
\hline & & Disagree & 23 & 9.6 \\
\hline & & Normal & 74 & 30.8 \\
\hline & & Agree & 76 & 31.7 \\
\hline
\end{tabular}




\begin{tabular}{|c|c|c|c|c|}
\hline & & $\begin{array}{l}\text { strongly } \\
\text { agree }\end{array}$ & 53 & 22.1 \\
\hline \multirow[t]{5}{*}{10} & \multirow[t]{5}{*}{$\begin{array}{l}\text { The layout makes it easy to get to } \\
\text { the food area }\end{array}$} & $\begin{array}{l}\text { strongly } \\
\text { disagree }\end{array}$ & 22 & 9.2 \\
\hline & & Disagree & 19 & 7.9 \\
\hline & & Normal & 66 & 27.5 \\
\hline & & Agree & 83 & 34.6 \\
\hline & & $\begin{array}{l}\text { strongly } \\
\text { agree }\end{array}$ & 50 & 20.8 \\
\hline \multirow[t]{5}{*}{11} & \multirow[t]{5}{*}{$\begin{array}{l}\text { The layout makes it easy to get to } \\
\text { the restroom }\end{array}$} & $\begin{array}{l}\text { strongly } \\
\text { disagree }\end{array}$ & 22 & 9.2 \\
\hline & & Disagree & 26 & 10.8 \\
\hline & & Normal & 71 & 29.6 \\
\hline & & Agree & 72 & 30.0 \\
\hline & & $\begin{array}{l}\text { strongly } \\
\text { agree }\end{array}$ & 49 & 20.4 \\
\hline \multirow[t]{5}{*}{12} & \multirow[t]{5}{*}{$\begin{array}{l}\text { The layout makes it easy to get } \\
\text { around }\end{array}$} & $\begin{array}{l}\text { strongly } \\
\text { disagree }\end{array}$ & 27 & 11.3 \\
\hline & & Disagree & 30 & 12.5 \\
\hline & & Normal & 69 & 28.8 \\
\hline & & Agree & 68 & 28.3 \\
\hline & & $\begin{array}{l}\text { strongly } \\
\text { agree }\end{array}$ & 46 & 19.2 \\
\hline \multirow[t]{5}{*}{13} & \multirow[t]{5}{*}{$\begin{array}{l}\text { The variety of food offered at the } \\
\text { center is excellent }\end{array}$} & $\begin{array}{l}\text { strongly } \\
\text { disagree }\end{array}$ & 25 & 10.4 \\
\hline & & disagree & 39 & 16.3 \\
\hline & & Normal & 66 & 27.5 \\
\hline & & Agree & 62 & 25.8 \\
\hline & & $\begin{array}{l}\text { strongly } \\
\text { agree }\end{array}$ & 48 & 20.0 \\
\hline \multirow[t]{5}{*}{14} & \multirow[t]{5}{*}{$\begin{array}{l}\text { The centers have an excellent } \\
\text { variety of stores }\end{array}$} & $\begin{array}{l}\text { strongly } \\
\text { disagree }\end{array}$ & 30 & 12.5 \\
\hline & & Disagree & 35 & 14.6 \\
\hline & & Normal & 59 & 24.6 \\
\hline & & Agree & 66 & 27.5 \\
\hline & & $\begin{array}{l}\text { strongly } \\
\text { agree }\end{array}$ & 50 & 20.8 \\
\hline \multirow[t]{4}{*}{15} & \multirow[t]{4}{*}{$\begin{array}{l}\text { The centers have excellent } \\
\text { entertainment alternative }\end{array}$} & $\begin{array}{l}\text { strongly } \\
\text { disagree }\end{array}$ & 22 & 9.2 \\
\hline & & disagree & 42 & 17.5 \\
\hline & & Normal & 72 & 30.0 \\
\hline & & Agree & 59 & 24.6 \\
\hline
\end{tabular}




\begin{tabular}{|c|c|c|c|c|}
\hline & & $\begin{array}{l}\text { strongly } \\
\text { agree }\end{array}$ & 45 & 18.8 \\
\hline \multirow[t]{5}{*}{16} & \multirow[t]{5}{*}{$\begin{array}{l}\text { I like to stay at centers as long as } \\
\text { possible }\end{array}$} & $\begin{array}{l}\text { strongly } \\
\text { disagree }\end{array}$ & 28 & 11.7 \\
\hline & & Disagree & 43 & 17.9 \\
\hline & & Normal & 89 & 37.1 \\
\hline & & Agree & 41 & 17.1 \\
\hline & & $\begin{array}{l}\text { strongly } \\
\text { agree }\end{array}$ & 39 & 16.3 \\
\hline \multirow[t]{5}{*}{17} & \multirow[t]{5}{*}{ I enjoy spending time at malls } & $\begin{array}{l}\text { strongly } \\
\text { disagree }\end{array}$ & 23 & 9.6 \\
\hline & & Disagree & 23 & 9.6 \\
\hline & & Normal & 93 & 38.8 \\
\hline & & Agree & 62 & 25.8 \\
\hline & & $\begin{array}{l}\text { strongly } \\
\text { agree }\end{array}$ & 39 & 16.3 \\
\hline
\end{tabular}

\section{RESULTS}

This research targeted females more than males and the reason are that females in general tend to have better interest in shopping than males. As seen in table (1) that 114 of the participants were male and 126 were females. In questionnaire the researchers used four group of ages to have a wider view on the need of shopping in different age people. The first group are the ones that their age is below 20 and the second category is for the people who are from $(21-30)$, the third one is $(31-40)$ the last category is for the people above 40.34 were below 20 and 119 participants were from (21-30) and 51 were from (31-40) and 36 were above 40 . As the results above showed us that the candidates participated in the questionnaire in the KRG are mostly in the ages (21-30) and that was the key targeted group of people in this research. In the third question when asking students and recently graduated students, students in different level of education about shopping it was clear that the juniors are the ones that show the most interest in shopping more than the rest of the students that filled this survey. The fourth question was about the occupation of the participants, the findings showed that the occupation of the participants were as below 120 students, 24 housewife, 16 were professional, 21 administrative, 12 business, 4 were clerical, 11 were sales, 13 were manufacturing, 9 were selfemployment and 10 from other sectors like market owners. This question helped us in the research to find out which occupation was affected the most in this economic crisis that accrued in the last year. The fifth question was about the income of the family we find that the income of the participants. 80 were below \$2000, 71 were from (\$2001-
\$3000), 37 were (\$3001-\$4000), 12 were (\$4001-\$5000), 15 were (\$5001-\$6000), 14 were (\$6001-\$7000) and only 11 were above $\$ 7000$. The graph above showed the fact that the highest number of the people affected by the current economic crisis are $(33.3 \%)$ of the population in KRG. and this population are the ones that their monthly payment is below 2000\$. The sixth and seventh question in this research was about the music that shopping centers play and how do the visitors like it $38.3 \%$ of the visitors felt that the music in the mall was normal, which means not the music that they like but at the same time it did not bother them. And when asking about the volume of the music the highest number of visitors were responded as normal as well. The eighth and ninth question was about the atmosphere of the center number eight question was about the lightening in the mall as a respond the highest number of comers to the mall agreed that the lightening of the mall is appropriate. The ninth question was about the temperature of the mall and the result was that majority of people which makes $32.1 \%$ thought that the temperature of the mall was normal. The next four questions dealt with the look of the mall and its effect. tenth and eleventh question was about the look and architecture view of the mall and how much it has effect on the attraction of the mall as a result $45 \%$ of the visitors totally agreed that the architecture look of the mall has a huge effect on the attraction of the mall while answering the twelfths question about the interior wall and floor design the highest number of visitors felt normal about it. $28.8 \%$ of the visitors in the mall thought that the decoration of the mall is normal not too good not too bad. Answering the question of the overall design of the center if it was interesting or not 
the responds were as below $33.8 \%$ of the population agreed that the overall design of the center interest them in their shopping. While $14.2 \%$ of the population disagreed and had no interest in the overall design. $28.3 \%$ of the population thought that the look of the mall was acceptable. $18.3 \%$ strongly agreed that their ability to do shopping increased with the overall look of the shopping center, the better the design was the times of their visit to the center increased. $5.4 \%$ of the population were not interested in the way the center looked. Questions number 14.15.16.17 were about the layout in the mall does it make finding places in the mall easier or there is no need for having layout due to the reason that the shopping centers that we have in KRG are not that large. As a respond from the visitors on having layout to help them find different places in the mall people agreed on the importance of having layouts, $31.7 \%$ agreed that the layout of the center is important and it makes getting to stores easier. $34.6 \%$ of the visitors agreed and thought that layout makes it easy to get to the food area. . $28.3 \%$ of the visitors that participated in this research agreed with having layout in center and the help they provide with getting around the mall. Question eighteenth deals with the variety of food provided in the center the replies for this question were as shown below, $27.5 \%$ of the costumers in the center thought that the quality of the food in the mall was normal for them. $25.8 \%$ agreed that the food in the center is excellent. $20 \%$ strongly agreed with the quality of the food offered in the center and voted for it as it's their favorite place. $16.3 \%$ of the center visitors disagreed with having to eat in the center and the food served in the mall got a low rate from them. $10.4 \%$ of the visitors in the mall strongly disagreed with the Excellency of the food offered in the center. Question nineteenth was about the diversity of stores available in the center that offers different kind of products that fulfill different needs and wants of costumers, this is how costumers responded $27.1 \%$ of the costumers in the center were not satisfied with the number of different stores in the mall that offered different products. $12.5 \%$ strongly disagreed with the verity of stores and $14.6 \%$ disagreed that there are a lot of different options in the center. $24.6 \%$ believed that the number of stores is ok. $27.5 \%$ agreed on the verity of stores and were satisfied. $20.8 \%$ strongly agreed that the Varity of stores in the mall is perfect. Question number twenty was about the quality of entertainment alternatives and fun activities in the center the responds were like this $18.8 \%$ strongly agreed that besides shopping there are a lot of entertainment activities within the center that a visitor can enjoy. $24.6 \%$ agreed that the entertainment alternatives are excellent. $30 \%$ of the costumers found that the fun activities in the mall were normal. 9.2\% strongly disagreed and did not like the entertainment alternatives. $17.5 \%$ disagreed on the entertainment alternatives available.
The last two question in the research dealt with the period of time that individuals spent at the mall and the last question was whether they enjoy that time or they are there because they have to, $37.1 \%$ of the mall visitors felt that it is normal to stay in the mall and that they don't mind. $17.1 \%$ agree that they would like to stay in the mall as long as possible, $16.3 \%$ strongly agree with the fact that staying in the mall is very fun and they would spend their whole day in the center if they could. $11.7 \%$ of the costumers of the mall for some reason didn't like to spend too much time in the center and they would rather do their shopping and leave. $17.9 \%$ of the center only visit it to get their needs and leave as fast as they could. The results showed us that the majority comers to the mall do not mind spending time in the center. And when they are asked if they enjoy their time there or not they reacted as below $38.8 \%$ felt normal with their visit to the mall. While the $25.8 \%$ agreed that they enjoyed their visit to the mall a. $16.3 \%$ strongly agreed on the fact that they have lots of fun in the mall and enjoy their time. With that percentage combined $80.9 \%$ of the visitors in the mall enjoy the time they spent with their family and friends in the mall shopping and doing enjoyable activities. $9.6 \%$ of the visitors seem to disagree with the rest of visitors and they did not enjoy the time they have spent in the mall. $9.6 \%$ strongly disagreed with the center being an enjoyable place.

\section{CONCLUSION}

The economic crisis that accrued has affected the citizens of the KRG in many ways. In this research the impact of the financial difficulties that people are facing and the impact of economy on the modern shopping attractions was not noticeable. The citizens of KRG due to not getting their monthly payments they could no longer spend money on shopping like the years before the crisis, yet they still go to shopping. And that has impacted the shopping malls and the workers in the malls. This research aimed at showing the shopping value, consumer decision making style, the importance of mall image and the costumer's loyalty to the malls. The contribution of the shopping centers to the economy reduced with the reduction of visitors and the low demand on the products. Many shops closed their doors because of the high rent payment and low revenue. If the economic crisis continues the middle-class people will no longer be able to take the shopping center as their shopping destination, and they would rather choose other lower price shopping options. It is extremely vital for mall administration to recognize the customers' needs and wants in order to inspire them to stay committed to shopping malls. The outcome of this study will contribute to the mall's management in planning numerous strategies such as 
providing easily accessibility and how to cope with economic crisis and financial insecurities', offer faithfulness program and packages and structure a mall image to accomplish the shoppers' anticipations and to additional attract repeating stopover to the malls.

\section{REFERENCES}

[1] Mamur, N. (2020). A Critical Analysis of Aesthetics and Cultural Texture of Shopping Malls in Teacher Education: The Ideology of Space. International Journal of Education \& the Arts, 21(27).

[2] Abdullah, N. N., \& Othman, M. B. (2019). Effects of Intellectual Capital on the Performance of Malaysian Food and Beverage Small and Medium-Sized Enterprises. International Journal of Civil Engineering and Technology (IJCIET), 10(2), 135-143.

[3] Anwar, G., \& Abdullah, N. N. (2021). Inspiring future entrepreneurs: The effect of experiential learning on the entrepreneurial intention at higher education. International Journal of English Literature and Social Sciences, 6.

[4] Hu, H., Zhang, Y., \& He, N. (2021). Research on the New Development Mode of Metro TOD Based on Tourism Economy_-Taking Shijiu Lake Scenic Area in Nanjing as an Example. In IOP Conference Series: Earth and Environmental Science (Vol. 693, No. 1, p. 012052). IOP Publishing.

[5] Gardi, B., Hamawandy, N. M., Vian Sulaiman Hama Saeed, R. M. A., Sulaiman, A. A., Mahmood, S. A., \& Al-Kake, F. A. (2020). The Effect of Capital Competence on the Profitability of Development and Investment Banks in Turkey. Solid State Technology, 63(6), 12571-12583.

[6] Prabhu, M., Nambirajan, T., \& Abdullah, N. N. (2020). Operating competitive priorities of manufacturing firms: An analytical study. Journal of Industrial Engineering and Management, 13(1), 38-55.

[7] Anwar, G., \& Shukur, I. (2015). The Impact of Training and Development on Job Satisfaction: A Case Study of Private Banks in Erbil. International Journal of Social Sciences \& Educational Studies, 2(1), 65.

[8] Abdullah, N. N., \& Othman, M. (2015). Disaster Management: Empirical Study of 2009 Jeddah Flood. Abdullah, NN \& Othman, M.(2015). Disaster Management: Empirical Study of, 1083-1087.

[9] Gardi, B. (2021). Investigating the effects of Financial Accounting Reports on Managerial Decision Making in Small and Medium-sized Enterprises. Turkish Journal of Computer and Mathematics Education (TURCOMAT), 12(10), 2134-2142.

[10] Anwar, G., \& Shukur, I. (2015). Job satisfaction and employee turnover intention: A case study of private hospital in Erbil. International Journal of Social Sciences \& Educational Studies, 2(1), 73.

[11] Ismael, N. B., Sorguli, S., Aziz, H. M., Sabir, B. Y., Hamza, P. A., Gardi, B., \& Al-Kake, F. R. A. (2021). The Impact of COVID-19 on Small and Medium-Sized Enterprises in Iraq.
Annals of the Romanian Society for Cell Biology, 24962505.

[12] Anwar, G., \& Shukur, I. (2015). the impact of recruitment and selection on job satisfaction: Evidence from private school in Erbil. International Journal of Social Sciences \& Educational Studies, 1(3), 4-13.

[13] Gardi, B. (2021). The effects of computerized accounting system on auditing process: a case study from northern Iraq. Available at SSRN 3838327.

[14] Anwar, G., \& Abd Zebari, B. (2015). The Relationship between Employee Engagement and Corporate Social Responsibility: A Case Study of Car Dealership in Erbil, Kurdistan. International Journal of Social Sciences \& Educational Studies, 2(2), 45.

[15] Anwar, G., \& Surarchith, N. K. (2015). Factors Affecting Shoppers' Behavior in Erbil, Kurdistan-Iraq. International Journal of Social Sciences \& Educational Studies, 1(4), 10.

[16] Othman, B. J., Al-Kake, F., Diah, M. L. M., Othman, B., \& Hasan, N. M. (2019). This study examines the antecedents and the effects of knowledge management and information technology in the manufacturing industry. International Journal of Psychosocial Rehabilitation, 23(02).

[17] Khan, S. \& Abdullah, N. N. (2019). The effect of ATM service quality on customer's satisfaction and loyalty: an empirical analysis. RJOAS, 5(89): DOI 10.18551/rjoas.2019-05.28

[18] Anwar, G., \& Shukur, I. (2015). The Impact of Service Quality Dimensions on Students' Satisfaction. International Journal of Social Sciences \& Educational Studies, 76.

[19] Othman, B. J., Al-Kake, F., Diah, M. L. M., Othman, B., Hussein, S., \& Hasan, N. M. (2019). Impact of the foreign direct investment on the economy of the United Kingdom. International Journal of Psychosocial Rehabilitation, 23(02).

[20] Anwar, K. (2017). Analyzing the conceptual model of service quality and its relationship with guests'satisfaction: A Study Of Hotels In Erbil. The International Journal of Accounting and Business Society, 25(2), 1-16.

[21] Anwar, K. (2016). Comparison between cost leadership and differentiation strategy in agricultural businesses. Custos $\mathrm{E}$ Agronegocio on Line, 12(2), 212-231.

[22] Abdullah, M. S., Toycan, M., \& Anwar, K. (2017). The cost readiness of implementing e-learning. CUSTOS E AGRONEGOCIO ON LINE, 13(2), 156-175

[23] Anwar, K., \& Balcioglu, H. (2016). The relationship between transformational leadership characteristics and effectiveness: A case study of construction companies in Erbil. International Journal of Science Technology and Management, 5(2), 250-256.

[24] Abdullah, N. N., \& Abdul Rahman, M. (2015). The Degree of Openness in Turkey's Public Expenditure. International Journal of Administration and Governance, 12(1), 8-12.

[25] Anwar, K. (2017). The Role of Effective Leadership in Crisis Management: Study of Private Companies in Kurdistan. Qalaai Zanist Scientific Journal, 2(4), 326-338.

[26] Hameed, A. A., \& Anwar, K. (2018). Analyzing the Relationship between Intellectual Capital and Organizational Performance: A Study of Selected Private 
Banks in Kurdistan. International Journal of Social Sciences \& Educational Studies, 4(4), 39.

[27] Damit, D. H. D. A., Harun, A., Martin, D., Othman, B., \& Ahmad, H. (2019). What makes a non-Muslim purchase halal food in a Muslim country? An application of theory of planned behaviour. Management Science Letters, 9(12), 2029-2038.

[28] Anwar, K., \& Ghafoor, C. (2017). Knowledge management and organizational performance: A study of private universities in Kurdistan. International Journal of Social Sciences \& Educational Studies, 4(2), 53.

[29] Prabhu, M., Thangasamy, N., \& Nawzad Abdullah, N. (2020). Analytical review on competitive priorities for operations under manufacturing firms. Journal of Industrial Engineering and Management, 13(1), 38-55

[30] Anwar, K., \& Climis, R. (2017). Analyzing the relationship between types of advertisement and customer choice: a study of retailer stores in erbil. The International Journal of Accounting and Business Society, 25(2), 43-52.

[31] Anwar, K. (2017). Factors Affecting Stock Exchange Investment In Kurdistan. The International Journal of Accounting and Business Society, 25(1), 32-37.

[32] Prabhu, M., Abdullah, N. N. \& Mohan, M. G. (2019). An Empirical Study on the Satisfaction Level of National and International Tourists towards Natural Attractions in Kurdistan. African Journal of Hospitality, Tourism and Leisure, 8 (2). 1-8

[33] Anwar, K., \& Qadir, G. H. A Study of the Relationship between Work Engagement and Job Satisfaction in Private Companies in Kurdistan. International Journal of Advanced Engineering, Management and Science, 3(12), 239944.

[34] Abdullah, NN \& Rahman, MFA (2015). The Use of Deliberative Democracy in Public Policy Making Process. Public Policy and Administration Research, 5(3), 221-229.

[35] Anwar, K. Leading Construction Project Teams: The Effectiveness of Transformational Leadership in Dynamic Work Environments in Kurdistan. International Journal of Advanced Engineering, Management and Science, 3(10), 239925.

[36] Abdullah, N. N. (2019). Probing the Level of Satisfaction towards the Motivation Factors of Tourism in Kurdistan Region. Scholars Journal of Economics, Business and Management, 5 (6). 439-443.

[37] Anwar, K., \& Louis, R. (2017). Factors Affecting Students' Anxiety in Language Learning: A Study of Private Universities in Erbil, Kurdistan. International Journal of Social Sciences \& Educational Studies, 4(3), 160.

[38] Ali, B. J., \& Anwar, G. (2021). The Effect of Marketing Culture Aspects of Healthcare Care on Marketing Creativity. Ali, BJ, \& Anwar, G.(2021). The Effect of Marketing Culture Aspects of Healthcare Care on Marketing Creativity. International Journal of English Literature and Social Sciences, 6(2), 171-182.

[39] Ali, B. J., \& Anwar, G. (2021). An Empirical Study of Employees' Motivation and its Influence Job Satisfaction. Ali, BJ, \& Anwar, G.(2021). An Empirical Study of Employees' Motivation and its Influence Job
Satisfaction. International Journal of Engineering, Business and Management, 5(2), 21-30.

[40] Khan, S. I., \& Abdullah, N. N. (2019). The impact of staff training and development on teachers' productivity. Economics, Management and Sustainability, 4(1), 37-45

[41] Ali, B. J., \& Anwar, G. (2021). The balanced scorecard's evolution as a strategic mechanism at banking sectors. Ali, BJ, \& Anwar, G.(2021). The Balanced Scorecard'S Evolution as a Strategic Mechanism at Banking Sectors. International Journal of English Literature and Social Sciences, 6(1), 471-478.

[42] Anwar, G., \& Abdullah, N. N. (2021). The impact of Human resource management practice on Organizational performance. International journal of Engineering, Business and Management (IJEBM), 5.

[43] Abdullah, N. N., \& Anwar, G. (2021). An Empirical Analysis of Natural Gas as an Alternative Fuel for Internal Transportation. International Journal of English Literature and Social Sciences, 6(1).

[44] Ali, B. J., \& Anwar, G. (2021). Factors Influencing the Citizens' Acceptance of Electronic Government. International journal of Engineering, Business and Management (IJEBM), 5.

[45] Anwar, G., \& Abdullah, N. N. (2021). Inspiring future entrepreneurs: The effect of experiential learning on the entrepreneurial intention at higher education. International Journal of English Literature and Social Sciences, 6.

[46] Prabhu, M., Abdullah, N.N., Ahmed, R.R. (2020). Segmenting the manufacturing industries and measuring the performance: using interval-valued triangular fuzzy TOPSIS method. Complex Intell. Syst.. https://doi.org/10.1007/s40747-020-00157-0

[47] Ali, B. J., \& Anwar, G. (2021). A study of knowledge management alignment with production management: A study of carpet manufacture in Kurdistan region of Iraq. Ali, BJ, \& Anwar, G.(2021). A Study of Knowledge Management Alignment with Production Management: a Study of Carpet Manufacture in Kurdistan Region of Iraq. International Journal of English Literature and Social Sciences, 6(2), 346-360.

[48] Ganeshkumar, C., Prabhu, M., \& Abdullah, N. N. (2019). Business Analytics and Supply Chain Performance: Partial Least Squares-Structural Equation Modeling (PLS-SEM) Approach. International Journal of Management and Business Research

[49] Ali, B. J., \& Anwar, G. (2021). Business strategy: The influence of Strategic Competitiveness on competitive advantage. International Journal of Electrical, Electronics and Computers, 6(2).

[50] Abdullah, N. N. \& Afshar, P. A. (2019). Investigating research and development costs on the profitability of Iranian industries. Journal of Organizational Behavior Research. Volume 4 (S2). 1-14

[51] Ali, B. J., \& Anwar, G. (2021). Marketing Strategy: Pricing strategies and its influence on consumer purchasing decision. Ali, BJ, \& Anwar, G.(2021). Marketing Strategy: Pricing strategies and its influence on consumer purchasing 
decision. International journal of Rural Development, Environment and Health Research, 5(2), 26-39.

[52] Abdullah, NN, \& Rahman, MFA (2015). Access to Government Information in Public Policy Making Process: A Case Study of Kurdistan. International Information Institute (Tokyo). Information, 18(8), 3447

[53] Ali, B. J., Saleh, P. F., Akoi, S., Abdulrahman, A. A., Muhamed, A. S., Noori, H. N., \& Anwar, G. (2021, May). Impact of Service Quality on the Customer Satisfaction: Case study at Online Meeting Platforms. In Ali, BJ, Saleh, Akoi, S., Abdulrahman, AA, Muhamed, AS, Noori, HN, Anwar, G.(2021). Impact of Service Quality on the Customer Satisfaction: Case study at Online Meeting Platforms. International journal of Engineering, Business and Management (Vol. 5, No. 2, pp. 65-77).

[54] Abdullah, N. N. (2018). Probing the Level of Satisfaction towards the Motivation Factors of Tourism in Kurdistan Region. 5(6), 439-443. DOI: 10.21276/sjebm.2018.5.6.3

[55] Ali, B. J., \& Anwar, G. (2021). Strategic leadership effectiveness and its influence on organizational effectiveness. International Journal of Electrical, Electronics and Computers, 6(2).

[56] Saleh, P. F., Ali, B. J., Akoi, S., Najmalddin, B., Ali, R. S., \& Anwar, G. (2021). Factors affecting the Success of Female Entrepreneurs in Kurdistan. International journal of Engineering, Business and Management (IJEBM), 5.

[57] Othman, M., \& Abdullah, N. N. (2016). The Conceptual Assessment of Malaysian Entrepreneurship Environment and EO Economic Contribution. Journal of Resources Development and Management, 20, 15-20.

[58] Ali, B. J., \& Anwar, G. (2021). Intellectual capital: A modern model to measure the value creation in a business. Ali, BJ, \& Anwar, G.(2021). Intellectual capital: A modern model to measure the value creation in a business. International journal of Engineering, Business and Management, 5(2), 31-43.

[59] Abdullah, N. N., \& Othman, M. (2016). The Contribution of Human Capital Investment in the Growth of East Asian Economy-A Literature Review. Journal of Economic and Business Research, 22(1), 190-203.

[60] Ali, B. J., \& Anwar, G. (2021). Organization citizenship behaviour as a determining Factor in Business outcome. Ali, BJ, \& Anwar, G.(2021). Organization citizenship behaviour as a determining Factor in Business outcome. International journal of Rural Development, Environment and Health Research, 5(2), 17-25.

[61] Abdullah, N. N., \& Othman, M. B. (2021). Investigating the Limitations of Integrated Tasks on Youth Entrepreneurship in Kurdistan Region. Путеводитель предпринимателя, 14(2), 179-190.

[62] Abdullah, N. N., \& Abdul Rahman, M. (2015). Chinese Economic Activities and Interests in Developing Countries. Australian Journal of Basic and Applied Sciences, 9(25), 7986.

[63] Ali, B. J., \& Anwar, G. (2021). The mediation role of change management in employee development. Ali, BJ, \& Anwar, G.(2021). The Mediation Role of Change Management in
Employee Development. International Journal of English Literature and Social Sciences, 6(2), 361-374.

[64] Top, C., \& Ali, B. J. (2021). Customer satisfaction in online meeting platforms: Impact of efficiency, fulfillment, system availability, and privacy. Amazonia Investiga, 10(38), 7081. https://doi.org/10.34069/AI/2021.38.02.7

[65] Demir, A., Maroof, L., Sabbah Khan, N.U. and Ali, B.J. (2020), "The role of E-service quality in shaping online meeting platforms: a case study from higher education sector", Journal of Applied Research in Higher Education. https://doi.org/10.1108/JARHE-08-2020-0253

[66] Ali, B, J. (2021). Impact of consumer animosity, boycott participation, boycott motivation, and product judgment on purchase readiness or aversion of Kurdish consumers in Iraq. Journal of Consumers Affaires; 1-20. https://doi.org/10.1111/joca.12350

[67] Ali, B, J. (2020). Impact of COVID-19 on consumer buying behavior toward online shopping in Iraq. Economic studies journal. 18(42): 267-280. Retrieved from https://www.asjp.cerist.dz/en/article/134070

[68] Ali, B.J. (2021) Assessing (The impact) of advertisement on customer decision making: Evidence from an educational institution. Afak for sciences journal, 6(1): 425-439. Retrieved from https://www.asjp.cerist.dz/en/article/141056

[69] Ali, B.J. (2021) Consumer attitudes towards healthy and organic food in the Kurdistan region of Iraq. Management Science Letters. 11: 1-8. DOI: 10.5267/j.msl.2021.2.015

[70] Andavar, V., Ali, B.J., and Ali, S.A. (2020) Rainwater for Water Scarcity Management: An Experience of Woldia University (Ethiopia). Journal of Business, Economics and Environmental Studies, 10-(4): 29-34. DOI: 10.13106/jbees.2020.vol10.no4.29

[71] Faraj, K. M., Faeq, D. K., Abdulla, D. F., Ali, B. J., \& Sadq, Z. M. (2021). Total Quality Management And Hotel Employee Creative Performance: The Mediation Role Of Job Embeddedment. Journal of Contemporary Issues in Business and Government Vol, 27(1).

[72] Ali, B. J. (2016). Iraq Stock Market and its Role in the Economy. Retrieved from https://www.amazon.com/IraqStock-Market-Role-Economy/dp/3659634271

[73] Ali, B. J. (2014). Brand Building in the Consumer Electronics Industry in Iraq. Retrieved from https://www.amazon.com/Brand-Building-ConsumerElectronics-Industry/dp/6200248699

[74] Ali, B. J., \& Anwar, G. (2021). Capital Structure and Firm Profitability in Developing Countries. GOYA, 68(374), 163-174. Retrieved from https://goyajournal.org/index.php/goya/article/view/35

[75] Ali, B. J., \& Anwar, G. (2021). Factors Influencing the Citizens' Acceptance of Electronic Government. International Journal of Engineering, Business and Management, 5(1), 48-60. https://doi.org/10.22161/ijebm.5.1.5

[76] Ali, B. J., \& Anwar, G. (2021). The Effect of Marketing Culture Aspects of Healthcare Care on Marketing Creativity. International Journal of English Literature and Social Sciences, $\quad 6(2), \quad$ 171-182. https://doi.org/10.22161/ijels.62.25 
[77] Ali, B. J., \& Anwar, G. (2021). An Empirical Study of Employees' Motivation and its Influence Job Satisfaction. International Journal of Engineering, Business and Management, 5(2), 21-30. https://doi.org/10.22161/ijebm.5.2.3

[78] Ali, B. J., \& Anwar, G. (2021). The balanced scorecard's evolution as a strategic mechanism at banking sectors. International Journal of English Literature and Social Sciences, 6(1), 471-478. https://doi.org/10.22161/ijels.61.63

[79] Ali, B. J., \& Anwar, G. (2021). Self-Leadership Skills as Intangible Resources for Sustainable Competitive Advantage. Gongcheng Kexue Yu Jishu/Advanced Engineering Science, 46(1), 88-104. Retrieved from https://gongchengjournal.com/index.php/AES/article/view/10

[80] Ali, B. J., \& Anwar, G. (2021). Health sector reform: A Change Management Perspective on Health sector Reform. Gongcheng Kexue $\mathrm{Yu}$ Jishu/Advanced Engineering Science, 46(2), 29-38. Retrieved from https://gongchengjournal.com/index.php/AES/article/view/13

[81] Ali, B. J., \& Anwar, G. (2021). Organizational Learning as A Determining Factor in Firm Performance. GOYA, 68(374), 193-202. Retrieved from https://goyajournal.org/index.php/goya/article/view/40 